ECONOMIC THEMES (2020) 58(1): 131-148

S sciendo

DOI 10.2478/ethemes-2020-0008

\title{
ANALYSIS OF SUPLLY AND DEMAND FOR ELECTRONIC BANKING SERVICES IN THE SOUTH BAČKA REGION
}

\author{
Marija Vuković \\ Higher Business School of Professional Studies in Novi Sad, Republic of Serbia \\ $\triangle$ vlahmari3@gmail.com \\ Dejana Martinov \\ Higher Business School of Professional Studies in Novi Sad, Republic of Serbia \\ \martinovdejana91@gmail.com \\ Željana Mazić \\ Faculty of Economics and Engineering Management, Novi Sad, Republic of Serbia \\ $\bowtie$ zeljanamazic@outlook.com \\ UDC \\ 336.71:004 \\ Review \\ paper \\ Received: \\ 08.08.2019 \\ Accepted: \\ 20.04.2020

\begin{abstract}
The subject of this paper is the research of the electronic banking services market in the South Backa region. The aim of this paper is to systematise the supply of services by commercial banks. On the other hand, the aim of the paper is to evaluate the extent to which citizens use electronic banking services. The research methodology includes the application of the analytical method to the evaluation of the banking sector's supply of services, the survey method and the statistical processing of data in the empirical analysis of demand. The results of the research showed that there is a rich offer of electronic banking services
\end{abstract} \\ in the Republic of Serbia and that it is widely accepted. \\ Keywords: e-banking, pay cards, e-money, supply, demand \\ JEL classification: G21
}

\section{Introduction}

The subject of this paper is the analysis of the electronic banking services market in Novi Sad, as the regional center of the South Backa region. There are 26 commercial banks operating in the Serbian market. Most of them offer electronic 
banking services. The aim of the research is to determine the size of demand for these services by individuals in the South Backa region.The results obtained will be generalized at the level of the more developed parts of the Republic of Serbia.

Electronic banking has a number of advantages over traditional banking. The benefits are reflected in space and time, transaction speed and low cost. Customers are given greater control over their own accounts, easier access to cash, while making it easier for banks to penetrate the market.

The paper uses data from the website of the National Bank of Serbia, as well as that from the websites of specific commercial banks. As for the empirical research into the demand for e-banking services, the survey method and the statistical method were used to process the data collected.

The paper consists of four parts in addition to the Introduction and the Conclusion. The first part interprets the research to date on the topic, from literature analyzing issues in high-developed countries to research in developing countries, including Serbia. The theoretical and methodological part forms the second part of the research. The third part of the paper presents the results of an analysis of the offer of electronic banking services in the Republic of Serbia on the basis of data available on the website of the National Bank of Serbia. The fourth part of the paper summarizes the results of a survey conducted to collect information on demand for electronic banking services.

\section{Review of empirical literature}

The development of information and communication technologies is affecting financial institutions worldwide. Their evolution has transformed the way banks provide their services, using technologies such as ATMs, telephones, the Internet, credit cards and electronic money. In this spirit, banking in Serbia is undergoing changes. Many banks invest in internet technology to maintain a competitive edge. There is ample empirical evidence of this.

Different aspects of information and communication technologies in the context of a developing country are presented in the author's section Dospinescu \& Rus, 2006. There are two main points that explain the limited demand for ebanking services. First, because these services are expensive, that is, low-income individuals cannot pay financial transaction prices. An alternative view is that limited e-literacy serves as an important barrier to demand for e-banking services (Cole, Sampson \& Zia, 2009). In their research, the authors Kongaut \& Lis conclude that successful and widely accepted payment by mobile phone requires adequate technology and information infrastructure to accompany the growing demand for these services. The growing popularity of smartphones has spurred demand by making new payment technology available to large consumer groups. However, the use of mobile payment services could not have increased 
significantly without the introduction of applications (regulators) in each country or region. These authors believe that a good combination of regulation and / or supply and demand policies is the way to win new consumers.

The authors Raičević \& Matijašević in their work start from the hypothesis that electronic money and electronic banking, as a form of market communication, are necessary and conclude that it positively affects the speed and efficiency of business and that success depends on the effective protection of users' financial privacy. A number of indicators closely related to the satisfaction of users of ebanking services are indicated in his monograph Lacmanović, 2018, such as: customer support, application of new technologies, software tools and services, education strategy of the company in the field of electronic services and general computer literacy, importance security and data security in terms of users' trust in the electronic system of services. In the article, the authors Pavlović \& Mutibarić, 2016, conclude that the implementation of banking in Serbia has not reached the European level, so banks seek to educate citizens and instruct them to use this type of banking. Authors Pavlovic \& Savic, 2017, show in their empirical research that individuals' intentions to use mobile banking depend most on perceived financial cost and least on perceived utility.

The integrated research of supply and demand for e-banking services, which is the subject of this paper, fills the gap in the existing domestic literature as the findings confirm the initial hypotheses that become valid scientific knowledge and broaden the existing knowledge of consumer restrictions to use everything on supply.

\section{Theoretical and methodological framework}

The development of information and telecommunications technology has created the conditions for globalization of business. The main objective was to connect clients and information flows as quickly and efficiently as possible regardless of geographical distances (Živković, Stanković \& Krstic, 2012, pp.451-452).

The primary goal of introducing electronic payment systems was to solve the problems of paper based payment systems, but practice later showed that these processes are of greater importance, that is, the efficient and economical use of this technology requires the reengineering of business processes and the interrelations of participants. The biggest technological achievement in banking is the emergence of electronic banking and electronic money. E-commerce refers to running a business on the Internet, buying, selling, organizing business, taking care of clients and business partners.

Electronic banking has a number of advantages over the so-called traditional (branch) business of banks. They are mainly reflected in time and space, the speed of transactions, low cost and a wide range of banking products and services. The 
main advantage of electronic banking is that it is available 24 hours a day, 7 days a week. In a traditional banking business, a much larger number of people would need to be employed for such business hours, and thus the costs of doing business would be much higher. Spatial boundlessness is another of the benefits of ebanking. It can be done from anywhere in the world. All that is required is for the user to have an account with a bank providing electronic banking services and a computer with Internet access. In traditional business, the customer is tied to the country and branch of the bank where he has an account. Another advantage is the speed of transactions. While traditional banking takes time to go to the bank, wait at the counters, fill in forms or other documents, and take time to complete the transaction itself, electronic banking requires only time to register and time to complete the transaction. E-banking is the cheapest form of banking. The fees are the same or even lower than the fees in traditional banking.

In order to evaluate the state of electronic banking in Serbia, we must compare it with the situation in other more or less developed countries. For example, in France, the participation of electronic banking in the payment system is $70 \%$ or $80 \%$, while in Serbia it is only $1 / 3$, but it is relatively well developed in relation to some other segments and has a tendency for further development (Josanov \& Peric, 2005; p.126). The development of electronic banking is reflected in the technological and organizational infrastructure of the PDO (Bureau of Accounts and Payments) and in the habits of using their services for banks and businesses.

Comprehensive reforms of the financial system in the Republic of Serbia began in 2001, within which the banking sector reform was initiated (Lacmanović, 2015, pp.81-82). Prior to 2001, the banking sector lost its primary function of mobilising free funds and placing them in profitable projects and the country's economy. In 2000 , there were 84 commercial banks, of which $90 \%$ were socially owned. In December 2000, the National Bank of Serbia undertook measures to determine the true financial position of the banks, after which 23 operating licenses were withdrawn, the renowned European banks entered the market, and the total number of banks decreased to 53 banks. In 2019, the banking sector is comprised of 26 commercial banks. This is the result of the measures taken and the remediation under the reforms by the NBS.

Banks have successfully become involved in new interbank clearing systems according to world principles. The range of offerings has expanded. Through a computer or mobile phone, clients can check their account balance, view traffic and perform payments, and pay their dues. It offers the possibility of using ATMs, payment cards, POS terminals, call centers, all in order to provide clients with the provision of services throughout the day without going to the bank. In the area of payment card issuance and use, there is government support. Their interest is reflected in the fact that the use of cards implies a legal flow of money, since such payment requires the issuance of a fiscal invoice, which also involves the collection of taxes. 


\section{Results of analyse the supply for electronic bank services in Serbia}

This part of the paper analyses the supply of electronic banking services in the Republic of Serbia. E-banking in our country is not yet sufficiently developed due to various factors, but banks are trying to educate citizens and make it easier for them to carry out their daily operations by using this form of banking. At first, the banks themselves were afraid of introducing electronic banking, but with increasing competition they were almost forced to start introducing it.

When assessing the state of electronic banking in Serbia, it is important to compare it with the situation in more developed countries. With us, the participation of electronic banking is much lower than in other developed countries, but each is well developed and, most importantly, shows a tendency for further development. In Serbia, paper money is still the most trusted, but nonetheless, data show that citizens, especially businesses, are increasingly turning to e-banking.

Of the 26 banks operating in Serbia, most offer e-banking services. In order to use e-banking, users must sign a contract with a bank that defines terms, rights and obligations. The use of e-banking services is free in most cases, which is one of the advantages of e-banking. Table 1 shows the electronic banking services offered by commercial banks in the Republic of Serbia.

Table 1. Electronic banking services offered by banks in the Republic of Serbia

\begin{tabular}{||l|l|l||}
\hline \hline Bank business name & Population & Economy, agriculture, legal entities \\
\hline Addiko bank a.d. Beograd & $\begin{array}{l}\text { Addiko e-bank } \\
\text { Addiko mobile } \\
\text { SMS servis }\end{array}$ & $\begin{array}{l}\text { Personal e-bank (HALCOM) } \\
\text { Office Banking (ASSECO) }\end{array}$ \\
\hline $\begin{array}{l}\text { Agroindustrijsko } \\
\text { komercijalna banka AIK } \\
\text { bankaa.d. Beograd }\end{array}$ & $\begin{array}{l}\text { eBanking } \\
\text { mBanking }\end{array}$ & $\begin{array}{l}\text { Electronic banking } \\
\text { Mobile banking }\end{array}$ \\
\hline API Bank a.d. Beograd & E-bankarstvo & E-banking \\
\hline BancaIntesaa.a.d. Beograd & $\begin{array}{l}\text { Wave2Pay } \\
\text { IntesaMobi } \\
\text { Intesa on-line } \\
\text { SMS notifications }\end{array}$ & $\begin{array}{l}\text { Electric banking } \\
\text { e-comerce SMS i E-mail } \\
\text { E-bankingterminals }\end{array}$ \\
\hline $\begin{array}{l}\text { Banka Poštanska štedionica } \\
\text { a.d. Beograd }\end{array}$ & $\begin{array}{l}\text { Internet banking } \\
\text { Mobil banking }\end{array}$ & \\
& $\begin{array}{l}\text { SMS info } \\
\text { SMS query to state }\end{array}$ & \\
& $\begin{array}{l}\text { SMS recharge and } \\
\text { payment } \\
\text { Card alarm services }\end{array}$ & \\
\hline
\end{tabular}




\begin{tabular}{|c|c|c|}
\hline & $\begin{array}{l}\text { E-mail performs } \\
\text { Self-service } \\
\text { zone } 24 / 7\end{array}$ & \\
\hline \multicolumn{3}{|l|}{$\begin{array}{l}\text { Bank of China Srbijaa.d. } \\
\text { Beograd }\end{array}$} \\
\hline $\begin{array}{l}\text { Credit Agricole Banka } \\
\text { Srbijaa.d. Novi Sad }\end{array}$ & $\begin{array}{l}\text { ASSECO (Pexim) } \\
\text { Halcom e-bank } \\
\text { package } \\
\text { Le bank mobile } \\
(\mathrm{m} \text {-bank) }\end{array}$ & $\begin{array}{l}\text { ASSECO (Pexim) } \\
\text { Halcom e-bank package } \\
\text { m-bank }\end{array}$ \\
\hline \multicolumn{3}{|l|}{$\begin{array}{l}\text { Direktna banka } \\
\text { a.d.Kragujevac }\end{array}$} \\
\hline Expobanka.d. Beograd & $\begin{array}{l}\text { e-banking personal } \\
\text { (NETpersonal, } \\
\text { NETmail, } \\
\text { MOBILEsms) }\end{array}$ & $\begin{array}{l}\text { e-banking business } \\
\text { (NETbusiness,NETmail,MOBILEsms) }\end{array}$ \\
\hline Erste Bank a.d. Novi Sad & $\begin{array}{l}\text { netBanking } \\
\text { mToken } \\
\text { mBanking } \\
\text { novoMob }\end{array}$ & $\begin{array}{l}\text { NetBanking } \\
\text { NovoKlik } \\
\text { NovoMob } \\
\text { Halcom } \\
\text { Office banking } \\
\end{array}$ \\
\hline Eurobanka.d. Beograd & $\begin{array}{l}\text { e-banking } \\
\text { m-banking } \\
\text { telephone banking }\end{array}$ & $\begin{array}{l}\text { Mobile business banking } \\
\text { Asseco (Pexim) Office banking } \\
\text { Hal Ebank Personal }\end{array}$ \\
\hline Halkbanka.d. Beograd & $\begin{array}{l}\text { Electircal banking } \\
\text { Mobile banking } \\
\text { SMS information } \\
\text { service } \\
\text { payment by mobile } \\
\text { phone }\end{array}$ & $\begin{array}{l}\text { Electrical banking } \\
\text { Halkbank online }\end{array}$ \\
\hline $\begin{array}{l}\text { Jubmes Banka a.d. } \\
\text { Beograd }\end{array}$ & $\begin{array}{l}\text { E- banking } \\
\text { Home banking } \\
\text { mBanking }\end{array}$ & $\begin{array}{l}\text { E-banking } \\
\text { Home banking } \\
\text { mBanking }\end{array}$ \\
\hline $\begin{array}{l}\text { Komercijalna Banka a.d. } \\
\text { Beograd }\end{array}$ & $\begin{array}{l}\text { Electrical banking } \\
\text { SMS servis } \\
\text { mBank } \\
\text { Kombank trader }\end{array}$ & $\begin{array}{l}\text { e-bank } \\
\text { web e-bank } \\
\text { SMS servis } \\
\text { Kombank trader }\end{array}$ \\
\hline Mirabanka.d. Beograd & $\begin{array}{l}\text { Internet banking } \\
\text { m-bankarstvo }\end{array}$ & Electrical banking \\
\hline MTS Banka a.d. Beograd & Electrical banking & Electrical banking \\
\hline NLB Banka a.d. Beograd & $\begin{array}{l}\text { NLB eKlik } \\
\text { NLB mKlik }\end{array}$ & $\begin{array}{l}\text { NLB eKlik } \\
\text { NLB mKlik } \\
\text { NLB proKlik } \\
\end{array}$ \\
\hline $\begin{array}{l}\text { Opportunity Banka a.d. } \\
\text { Novi Sad }\end{array}$ & & $\begin{array}{l}\text { Electrical banking } \\
\text { Office banking } \\
\text { FX Client }\end{array}$ \\
\hline
\end{tabular}




\begin{tabular}{|c|c|c|}
\hline $\begin{array}{l}\text { Procredit Bank a.d. } \\
\text { Beograd }\end{array}$ & $\begin{array}{l}\text { Mobile banking } \\
\text { Internet banking } \\
\text { Telephone banking }\end{array}$ & $\begin{array}{l}\text { Mobile banking } \\
\text { Internet banking } \\
\text { Telephone banking }\end{array}$ \\
\hline $\begin{array}{l}\text { Raiffeisen Banka a.d. } \\
\text { Beograd }\end{array}$ & $\begin{array}{l}\text { Internet banking } \\
\text { Mobile banking } \\
\text { Telephone banking } \\
\text { SMS }\end{array}$ & $\begin{array}{l}\text { Reiffeisen online } \\
\text { Halcome-bankCMI@web } \\
\text { SWIFT MT101 } \\
\text { Mobile banking }\end{array}$ \\
\hline Sberbanka.d. Beograd & $\begin{array}{l}\text { e-bank } \\
\text { m-bank }\end{array}$ & Business online \\
\hline $\begin{array}{l}\text { SocieteGenerale Banka } \\
\text { Srbijaa.d. Beograd }\end{array}$ & $\begin{array}{l}\text { e-banking } \\
\text { m-banking } \\
\text { mobilia } \\
\text { vocalia } \\
\text { SMS instant } \\
\text { recharge } \\
\text { standing order }\end{array}$ & $\begin{array}{l}\text { HAL E-BANK } \\
\text { SOGE-BANKING } \\
\text { Business card } \\
\text { Vocalia } \\
\text { Mobilia }\end{array}$ \\
\hline Srpska Banka a.d. Beograd & $\begin{array}{l}\text { Electrical banking } \\
\text { Mobile banking } \\
\text { SMS service }\end{array}$ & Hal e-bank \\
\hline $\begin{array}{l}\text { Telenor Banka a.d. } \\
\text { Beograd }\end{array}$ & $\begin{array}{l}\text { Internet banking } \\
\text { Mobile banking }\end{array}$ & \\
\hline $\begin{array}{l}\text { Unicredit Bank Srbijaa.d. } \\
\text { Beograd }\end{array}$ & $\begin{array}{l}\text { mBanking } \\
\text { mToken } \\
\text { Online bank } \\
\text { bank at the button } \\
\text { (internet banking, } \\
\text { mobile } \\
\text { banking,cash } \\
\text { machine) }\end{array}$ & $\begin{array}{l}\text { Electrical banking } \\
\text { Unicredit e-banking }\end{array}$ \\
\hline $\begin{array}{l}\text { Vojvođanska Banka a.d. } \\
\text { Novi Sad }\end{array}$ & $\begin{array}{l}\text { iBank } \\
\text { mBank }\end{array}$ & $\begin{array}{l}\text { VobEbank } \\
\text { VobSMS }\end{array}$ \\
\hline
\end{tabular}

Source: Table created by the authors based on the offer the banks have on their site.

For both individuals and legal entities, it mainly covers mobile banking, internet banking, SMS, telephone banking. According to data from the banks' websites, we see that the richest offer is offered by Banca Intesa, Halkbank, Komercijalna Banka, Raiffeisen Bank, and Societe Generale Bank, which will be shown by an empirical study of demand for research.

Table 2 shows the amount of turnover made by non-cash transfer of funds in the Republic of Serbia in 2014 and 2015, given that the data on the website of the National Bank of Serbia as of 2015 end. 
Table 2. Cashless transfer of funds in 2014 and 2015, in millions of dinars

\begin{tabular}{|l|l|l|l|l||}
\hline & \multicolumn{2}{|c|}{2014} & \multicolumn{2}{c|}{2015} \\
\hline & $\begin{array}{l}\text { Number of } \\
\text { transactions } \\
\text { total }\end{array}$ & $\begin{array}{l}\text { Total } \\
\text { transaction } \\
\text { value* }\end{array}$ & $\begin{array}{l}\text { Number of } \\
\text { transactions } \\
\text { total }\end{array}$ & $\begin{array}{l}\text { Total value of } \\
\text { transactions }\end{array}$ \\
\hline $\begin{array}{l}\text { Electronic } \\
\text { Funds Transfer }\end{array}$ & 87.880 .894 & 12.684 .589 & 100.148 .513 & 14.778 .297 \\
\hline $\begin{array}{l}\text { Internet } \\
\text { banking }\end{array}$ & 86.731 .037 & 12.680 .214 & 97.432 .005 & 14.763 .847 \\
\hline $\begin{array}{l}\text { Mobile } \\
\text { banking }\end{array}$ & 870.394 & 3.695 & 2.285 .286 & 13.132 \\
\hline ATM & 279.463 & 680 & 440.222 & 11.320 \\
\hline
\end{tabular}

Source: National Bank of Serbia

From this analysis, it can be concluded that in 2015 there was a slight increase in internet banking and a much higher use of ATM devices and mobile banking. This also means a much greater customer confidence in the e-commerce of banks. Electronic funds transfer increased by $13.96 \%$ in 2015 , Internet banking recorded an increase of $12.34 \%$, while mobile banking $(162.56 \%)$ and use of ATM devices $(57.52 \%)$ recorded the highest growth in the observed period. Table 3 shows the number of clients by types of individual payment services in the Republic of Serbia for 2014 and 2015.

Table 3. Number of clients by types of individual payment services for 2014 and 2015.

\begin{tabular}{|l|l|l|l|l||}
\hline & \multicolumn{2}{|l|}{2014} & \multicolumn{2}{l|}{2015} \\
\hline Quarter & I & IV & I & IV \\
\hline $\begin{array}{l}\text { Total number } \\
\text { of clients }\end{array}$ & 8.517 .231 & 8.811 .973 & 8.774 .395 & 9.032 .298 \\
\hline $\begin{array}{l}\text { Internet } \\
\text { banking }\end{array}$ & 1.019 .637 & 1.153 .611 & 1.209 .521 & 1.421 .885 \\
\hline $\begin{array}{l}\text { Telephone } \\
\text { banking }\end{array}$ & 82.260 & 98.901 & 106.069 & 121.648 \\
\hline Mobile banking & 103.212 & 179.724 & 218.456 & 464.167 \\
\hline Standing order & 258.220 & 279.006 & 284.286 & 311.736 \\
\hline $\begin{array}{l}\text { Internet } \\
\text { banking } \\
\text { payment card }\end{array}$ & 1.902 .405 & 2.046 .054 & 2.074 .435 & 2.216 .610 \\
\hline $\begin{array}{l}\text { Internet } \\
\text { banking } \\
\text { internet card }\end{array}$ & 70.197 & 80.074 & 82.660 & 92.640 \\
\hline
\end{tabular}

Source: National Bank of Serbia 
The total number of clients using one of the e-banking services in 2015 increased by $2.5 \%$ compared to 2014 . That singing, though small, shows us that an increasing number of users are opting to use some of the e-banking services to do their jobs faster and easier.

Information on the number of cards issued in the Republic of Serbia was taken from the website of the National Bank of Serbia (https://www.nbs.rs/internet/ latinica/35/statistika/index.html). Table 4 shows the number of payment cards issued and their activity in the Republic of Serbia for 2014 and 2015.

Table 4. Number and activity of payment cards issued in the Republic of Serbia for 2014 and 2015, in millions

\begin{tabular}{|l|l|l|l|l|l|l|}
\hline \hline & 2014 & 2015 & \multicolumn{2}{l|}{} \\
\hline $\begin{array}{l}\text { The } \\
\text { quarter }\end{array}$ & $\begin{array}{l}\text { Delivered } \\
\text { in total }\end{array}$ & $\begin{array}{l}\text { Active } \\
\text { total }\end{array}$ & $\begin{array}{l}\text { Participation } \\
\text { of active* }\end{array}$ & $\begin{array}{l}\text { Delivered } \\
\text { in total }\end{array}$ & $\begin{array}{l}\text { Active } \\
\text { total }\end{array}$ & $\begin{array}{l}\text { Participation } \\
\text { of active }\end{array}$ \\
\hline I & 6.1 & 2.9 & $48 \%$ & 6.3 & 3.1 & $49 \%$ \\
\hline II & 6.1 & 2.9 & $48 \%$ & 6.4 & 3.2 & $49 \%$ \\
\hline III & 6.2 & 3.0 & $48 \%$ & 6.3 & 3.2 & $50 \%$ \\
\hline IV & 6.3 & 3.1 & $49 \%$ & 6.5 & 3.1 & $51 \%$ \\
\hline
\end{tabular}

Source: National Bank of Serbia

The total number of active payment cards issued in the Republic of Serbia increased by $6.13 \%$ in 2015 compared to 2014 , but their participation recorded almost no growth. Banks need to focus on gaining customer confidence in order to achieve satisfactory growth in the participation of active payment cards.

The payment card market in Serbia includes Visa, MasterCard, Diners, American Express and the national payment card DinaCard (www.kombeg.org.rs). Most banks in our banking system issue Visa payment cards, debit and credit cards, and it is the first in the number of payment cards issued. MasterCard is the second most issued card. The presence of Diners cards is slightly lower here. They are generally not issued by banks but by Diners Club International, and can be found in 5 banks. American Express cards are very poorly represented here and can only be found on the Bank of Intesa offer. DinaCard is also issued as a national card by most banks in Serbia.

\section{Results of the analysis of demand for electronic banking services in the South Backa region}

In the period from 8 to 28 March 2017, 70 citizens were surveyed in Novi Sad, using a random sample method, in order to collect information on the implementation of electronic banking in the Republic of Serbia. The following tables present the processed data and analyze the obtained research results. The 
questionnaire was taken from the author Pavlović \& Mutibarić, 2016, with some modifications adapted to the subject of the research.

Figure 1. Relationship with banks - graphical representation of obtained results
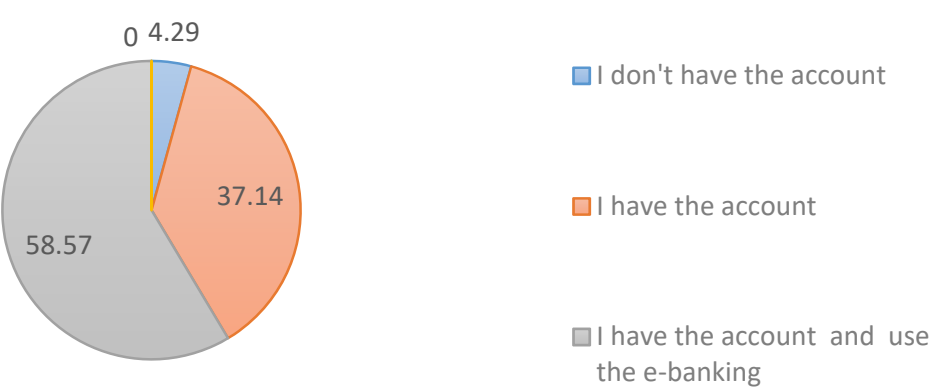

Source: authors

Based on the data in Figure 1, we can conclude that the largest number of respondents have a current account and use one of the e-banking services (58.57\%), which is a very good indicator, and banks should continue to work towards e-banking develops even more. Only $4.9 \%$ of respondents do not have a checking account and $37.14 \%$ do not use electronic banking.

Table 5. What are the motives of the bank to offer electronic banking services

\begin{tabular}{|l|l||}
\hline & $\begin{array}{l}\text { Number of } \\
\text { respondents }\end{array}$ \\
\hline To be tax exempt & 24 \\
\hline To attract more customers / consumers & 41 \\
\hline To contribute to the loyalty of their customers / consumers & 14 \\
\hline Because they feel a moral obligation & 6 \\
\hline They want to increase profits & 45 \\
\hline They want to reduce the number of employees & 45 \\
\hline They find that consumers / customers expect it from them & 10 \\
\hline To attract new customers & 41 \\
\hline Because so do their competitors & 26 \\
\hline They want to be part of trends in the developed world & 30 \\
\hline \hline
\end{tabular}

Source: authors 
Most respondents believe that banks' motives for providing electronic banking services are their desire to increase profits and reduce the number of employees, as well as to attract as many clients as possible. The use of electronic banking increases the profit of banks because it reduces the cost of conducting banking transactions, but also because the number of employees in branches decreases

Figure 2 shows citizens' views on electronic banking. The majority of citizens who participated in this survey use e-banking to use e-banking. $37.14 \%$ of citizens still do not use these services, but most of them, $25.71 \%$ are interested and want to know more about these services of banks. Banks should work even harder to bring these services closer to citizens, to provide them with more information about them, to make them more interested and to become their customers.

Figure 2. Identification and attitude of citizens on electronic banking - graphical representation of the obtained results

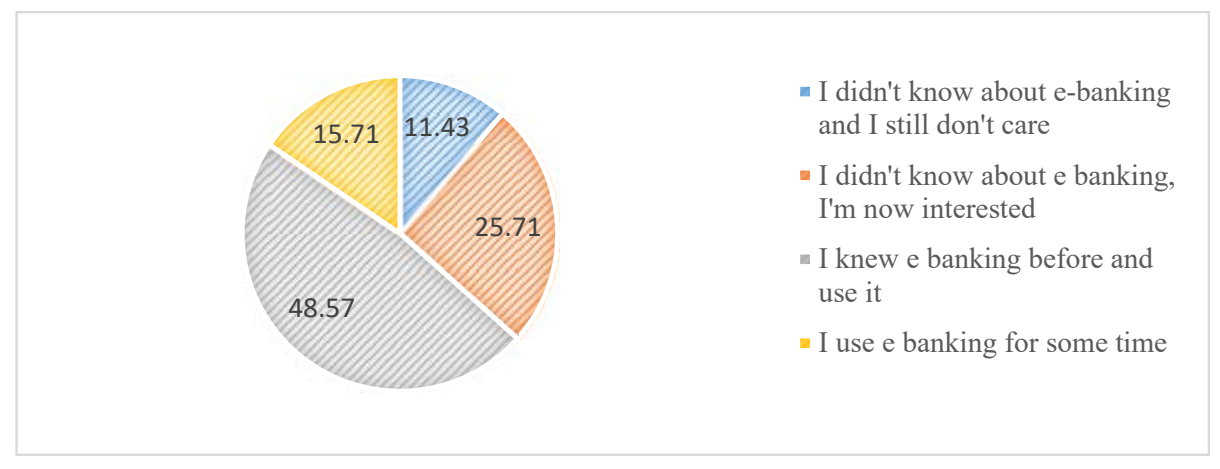

Source: authors

Table 6 shows the number of respondents who opted for particular forms of electronic banking.

Table 6. Forms of electronic banking

\begin{tabular}{||l|r||}
\hline \hline What kind of electronic banking do you use & Number of respondents \\
\hline Electronic Funds Transfer & 10 \\
\hline Internet banking & 15 \\
\hline Mobile banking & 26 \\
\hline None of the above & 28 \\
\hline
\end{tabular}

Source: authors 
Based on the data obtained, we can see that mobile banking is most prevalent among users, followed by internet banking. This is expected, since both mobile and internet banking make banking transactions easier as users save time, and fees for using these services are the same or even lower than bank fees.

Tables 7 and 8 give an overview of the number of respondents who opted for a particular type or a particular brand of payment card.

Table 7. Payment card types

\begin{tabular}{||l|l||}
\hline What type of payment card do you use & Number of respondents \\
\hline Debitne & 43 \\
\hline Kredit & 38 \\
\hline Business & 19 \\
\hline $\begin{array}{l}\text { I have been using e-banking for some time } \\
\text { now }\end{array}$ & 4 \\
\hline
\end{tabular}

Source: authors

Table 8. Payment card brands

\begin{tabular}{||l|r||}
\hline \hline What brand of payment card do you use & Number of respondents \\
\hline Dina & 8 \\
\hline Yuba & 1 \\
\hline Visa & 44 \\
\hline MasterCard/Maestro & 38 \\
\hline American Express & 0 \\
\hline Diners Club Card & 0 \\
\hline \hline
\end{tabular}

Source: authors

The most common payment cards are Visa and MasterCard / Maestro, credit and debit cards. Visa and MasterCard are two of the world's leading brands in the payment card market so their representation is not surprising. Visa offers Visa electron, Visa classic, Visa gold and other types of cards. MasterCard offers Maestro debit card, MasterCard business, MasterCard standard and other card types.

The assessment of electronic banking security by the respondents is presented on Figure 3. From this picture we can see that electronic banking in Serbia has a future. Citizens remain unsure of this type of banking, but believe that their money is more secure than uncertain when using e-banking (62.86\%). 
Figure 3. Security of electronic banking - graphical representation of the obtained results

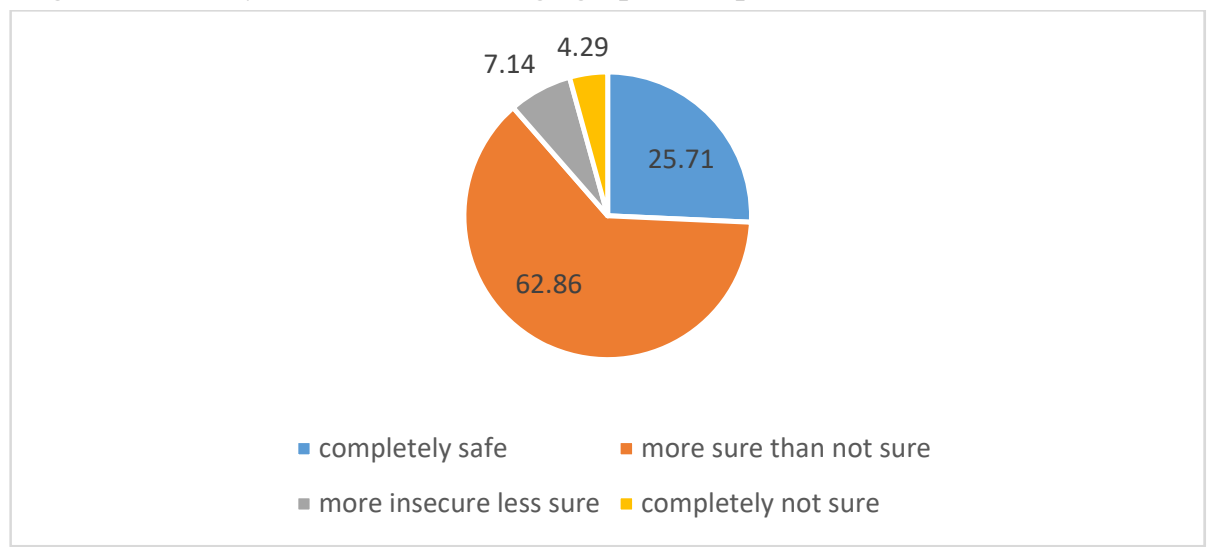

Source: authors

The following table shows the results of the respondents regarding their age.

Table 9. Respondents age data

\begin{tabular}{||l|r|r|r|r|r|}
\hline & \multicolumn{2}{|c|}{ Age range } & & \multicolumn{2}{|c|}{ Gender } \\
\hline$<25$ & 17 & 24,29 & Male & 34 & 48,57 \\
\hline $25-45$ & 29 & 41,43 & Female & 36 & 51,43 \\
\hline $45-65$ & 18 & 25,71 & & & \\
\hline$>65$ & 6 & 8,57 & & & \\
\hline
\end{tabular}

Source: authors

Figures 4 and 5 summarize the data on the work status and income of the respondent.

Figure 4. Response rate of respondents - graphical representation of obtained results

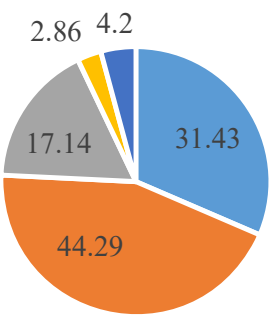

$\|<25000 \quad=25000-50000 \quad=50000-75000 \quad=75000-100000 \quad\|>100000$

Source: authors 
Figure 5. Respondent status - a graphical representation of the results obtained

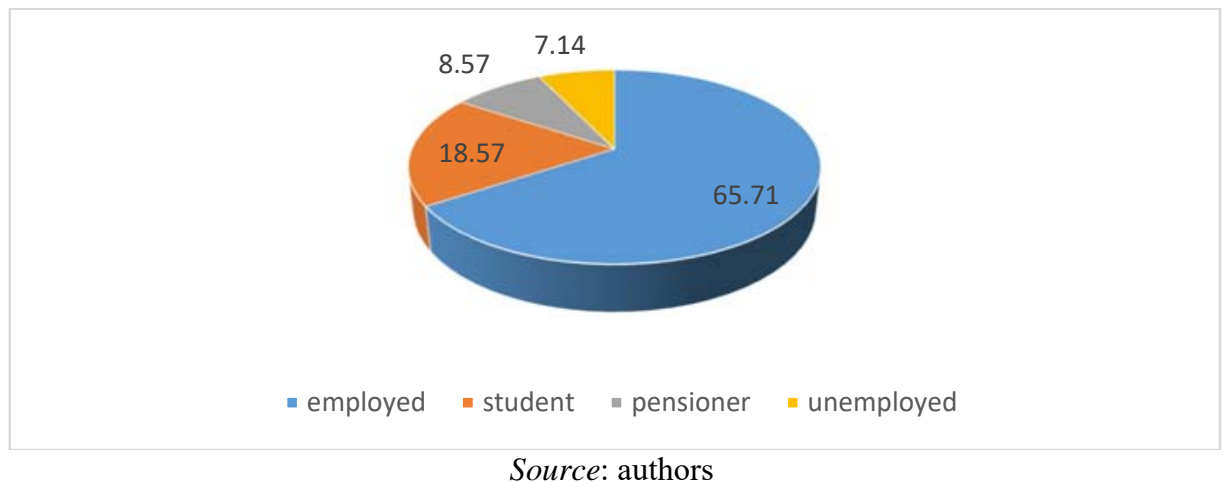

We can see that the largest number of interviewed citizens is between 25 and 45 years old $(41.43 \%)$, and that most of them are employed $(65.71 \%)$. Therefore, it is not surprising that most of them have current accounts and use e-banking. It saves them time that they probably don't even have in terms of work. Using ebanking services in just a few clicks on your computer or phone, they do a job that might otherwise require much more time at the banks. It can also be seen that most of them receive between 25,000 and 50,000 dinars, which is some average salary in Novi Sad.

Figure 6. Degree of education of the respondents - graphical representation of the obtained results

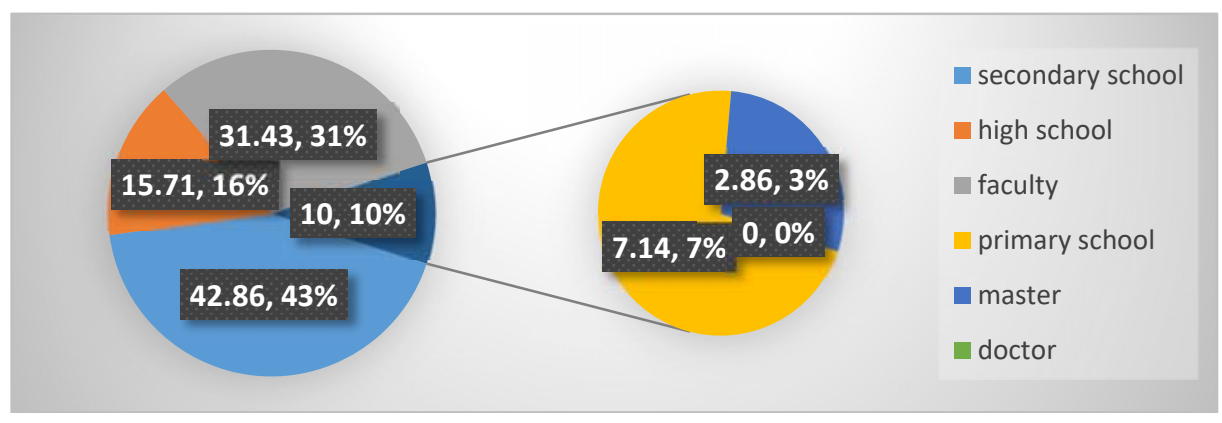

Source: authors

It can be seen that the highest number of respondents have completed high school $(42.86 \%)$, followed by college $(31.43 \%)$ and high school $(15.71 \%)$. In this way, the claim that highly educated people should have more knowledge and confidence in innovation is refuted. We live in a time when we are all aware of the fact that innovations that occur in all areas, including banking, actually make it easier for us to do our day-to-day business, which makes it less important what level of education someone has. 
Table 10. Sources of information on electronic banking services

\begin{tabular}{||l|r|r||}
\hline \hline Sources of information & $\begin{array}{c}\text { Number of } \\
\text { respondents }\end{array}$ & \multicolumn{1}{||}{$\%$} \\
\hline I learn about electronic banking from commercials & 29 & 41,43 \\
\hline I learn about electronic banking from the internet & 38 & 54,29 \\
\hline I learn about electronic banking from bank brochures & 41 & 58,57 \\
\hline
\end{tabular}

Source: authors

Most citizens are informed about banking services from bank brochures, which can be found in the halls of banks. Banks may need to work to get their e-banking service advertisements and advertisements in various media to further raise awareness among citizens and make them aware of their services, and to encourage even fewer does not always use these services in a future period opting for this form of banking.

Table 11. Banks where respondents have a current account

\begin{tabular}{||l|r|r||}
\hline Bank business name & Number of respondents & \multicolumn{2}{|c||}{} \\
\hline Addiko bank a.d. Beograd & 3 & 25,71 \\
\hline Alpha Bank Srbija a.d. Beograd & 18 & 5,71 \\
\hline Banca Intesa a.d. Beograd & 4 & 5,71 \\
\hline $\begin{array}{l}\text { Banka Postanska štedionica a.d. } \\
\text { Beograd }\end{array}$ & 4 & 17,14 \\
\hline $\begin{array}{l}\text { Credit Agricole Banka Srbija a.d. } \\
\text { Novi Sad }\end{array}$ & 2 & \\
\hline Direktna banka a.d. Kragujevac & 2 & \\
\hline Erste Bank a.d. Novi Sad & 1 & \\
\hline Eurobank a.d. Beograd & 1 & 12,86 \\
\hline Halkbank a.d. Beograd & 12 & \\
\hline Komercijalna Banka a.d. Beograd & 1 & \\
\hline NLB Banka a.d. Beograd & 1 & \\
\hline Opportunity Banka a.d. Novi Sad & 1 & \\
\hline OTP Banka Srbija a.d. Novi Sad & 1 & \\
\hline Piraeus Bank a.d. Beograd & 1 & \\
\hline Procredit Bank a.d. Beograd & 1 & \\
\hline Raiffeisen Banka a.d. Beograd & 1 & \\
\hline Sberbank a.d. Beograd & 1 & \\
\hline Unicredit Bank Srbija a.d. Beograd & 9 & \\
\hline Vojvođanska Banka a.d. Novi Sad & & \\
\hline
\end{tabular}

Source: authors 
The largest number of respondents has an open account at Banca Intesa (25.71\%), Komercijalna Banka (17.14\%) and Vojvodjanska Banka (12.86\%), which indicates that citizens have the highest confidence in them. As mentioned earlier, Intesa Bank has the richest offer of electronic banking and payment cards (Intesa Bank is the only bank in our banking system that issues American Express payment cards), and on the basis of this research we conclude that it also has the highest citizen confidence.

\section{Conclusion}

Electronic banking has evolved continuously since its inception. It has greatly improved the business. An increasing number of people want to manage their accounts electronically as they save time and are available 24 hours 7 days a week.

The advantage of e-commerce and e-banking is that it enables faster and easier international integrations for financial institutions as it significantly reduces the costs of transactions, administration and paperwork, and improves the archiving, retrieval and analysis of all transactions performed.

In Serbia, in the early stages of the development of electronic banking, outdated technology was a big problem, as was the population, which is very conservative when it comes to accepting any kind of newspaper. Today, we are witnessing an increasing use of e-banking services. In Serbia, the number of ATMs has increased significantly and their number is over 2800. Also, in our country there are over 8.2000 outlets with POS terminals, and their use is accepted by the population. More and more people are making payments with payment cards, not cash.

Survey results show that most respondents have current accounts and use some of the e-banking services, which indicates that it is already widely accepted. Banks should only continue to work in this direction to provide even more information to citizens about their services because even those who do not yet use these services want to know more about them, so that they themselves may become users of them because e-banking has many benefits for both customers and the bank. Banks should pay more attention to the development of mobile banking, as the number of mobile phone users is much higher than the number of computer users.

\section{References}

Cole Sh., Sampson Th. \& Zia, B. (2009).Prices or Knowledge? What Drives Demand for Financial Services in Emerging Markets? https://www.hbs.edu/faculty/Publication\%20Files/09-117.pdf

Ćosić, D. \& Radovanović, P. (2010). Elektronsko poslovanje i elektronsko bankarstvo, Visoka škola strukovnih studija, Beograd. 
Dospienescu, O. \&Rusu, D.(2006). The adoption of electronic banking services in developing countries - the Romanian case, https://www.researchgate.net/publication/228319519

Jošanov, B. \& Perić, D. (2005). Elektronsko poslovanje: pogled iz Srbije, Viša elektrotehnička škola, Beograd.

Kongaut, Ch. \&Lis, I.(2017). Supply and demand sides of mobile payment: A comparative analysis of successful mobile payment adoption in developed and developing countries, At: "Competition and Regulation in the Information Age", Passau, https://www.econstor.eu/bitstream/10419/169474/1/Kongaut-Lis.pdf

Lacmanović, I. (2015). Razvijenost elektronskog bankarstva u Republici Srbiji, Narodna biblioteka Srbije, Beograd, Isbn: 978-86-525-0245-5

Pavlović M. \&Mutibarić J. (2016).Značaj i primenaelektronskogbankarstva u Srbiji, Vojnodelo, br.2, str.242-262.

Pavlović, G. \&Savić, J. (2017).Determinantenamerapotrošača u pogledukorišćenjauslugamobilnogbankarstva, Marketing, vol.48, br.2, str.96-106.

Raičević,V., Matijašević, J. \&Ignjatijević, S. (2012).Ekonomskiefekti i pravniaspektielektronskogplaćanja, dostupnona internet adresi:

https://www.researchgate.net/publication/228319519_The_Adoption_of_Electronic_Banki ng_Services_in_Developing_Countries_-_The_Romanian_Case

Uroš, T. (2013). Elekktronsko bankarstvo, Visoka škola strukovnih studija, Beograd.

Vasković, V. (2008). Elektronsko poslovanje i internet marketing, Beograd.

Vuksanović, E. (2006). Elektronsko bankarstvo, Fakultet za bankarstvo,finansije i osiguranje, Beograd.

Vuksanović, E., (2009), Elektronski sistemi plaćanja, Kragujevac.

Vunjak, N., Kovačević, Lj., (2006), Bankarstvo, Ekonomski faklutet Subotica.

Živković, A. Stankić,R. \& Krstić, B. (2012). Bankarsko poslovanje i platni promet, Ekonomski fakultet Beograd.

\section{ANALIZA PONUDE I TRAŽNJE ZA USLUGAMA ELEKTRONSKOG BANKARSTVA U JUŽNOBAČKOM OKRUGU}

Rezime: Predmet istraživanja rada je istraživanje tržišta usluga elektronskog bankarstva u južnobačkom regionu.. Rad ima za cilj da izvrši sistematizaciju ponude usluga od strane poslovnih banaka. S druge strane, cilj rada je da ocenii u kojoj meri građani koriste usluge elektronskog bankarstva. Metodologija istraživanja obuhvata primenu analitičke metode pri oceni ponude usluga bankarskog sektora, metod ankete i statističku obradu podataka pri empirijskoj analizi tražnje. Rezultati istraživanja su pokazali da je bogata ponuda usluga elektronskog bankarstva u Republici Srbiji i da je prihvaćena u velikoj meri.

Ključne reči: elektronsko bankarstvo, platne kartice, elektronski novac, ponuda, tražnja. 


\section{Authors' biographies}

Marija Vuković (Vlahović), is a professor at the Higher Business School of Professional Studies in Novi Sad, the scientific field of Finance. It analyzes fiscal policy; design of the tax system in terms of fairness and efficiency; devising an adequate and responsible public spending policy; promoting sound fiscal decentralization; level of optimization of borrowing by central and local authorities and finding alternative options for borrowing. She is particularly interested in a gender-responsive approach to these issues.

Dejana Martinov is a specialist at the Higher Business School of Professional Studies in Novi Sad.

Željana Mažić is a student at the Faculty of Economics and Engineering Management. 